\section{Teaching Atlas of Brain Imaging}

edited by Nancy J. Fischbein, William P. Dillon, and A. James Barkovich, 630 pp, ill, New York, NY, Thieme Medical and Scientific Publishers, 1999, $\$ 129$

Although there are already a handful of neuroradiology teaching file atlases, this book, a part of Thieme's Teaching Atlas series, is a welcome addition. It is gleaned from the weekly Neuroradiology Section case conferences at the University of California at San Francisco. This is a big book of 630 pages of high-quality paper centered around 167 clinical cases well illustrated with large, high-resolution MR and CT images. The cases are logically arranged in 12 chapters representing the usual range of intracranial pathologies. There are also several excellent chapters focused on specific anatomic regions such as the cranial nerves or the meninges. Although the cases are presented following a one-sentence clinical history as "unknowns," because they are grouped into categories, the revealed diagnosis is usually not a complete surprise, as it can be in books arranged in a potpourri case conference fashion.

Following a brief listing of the case's imaging findings and differential diagnosis there is a discussion organized in short outlines and paragraphs divided into background, clinical findings, pathology, imaging findings, treatment, and prognosis. One of the highlights of the book is the use of sidebars with pearls and pitfalls pertaining to each case. These can help the timechallenged reader rapidly glean the key points. There are also occasional tables associated with the cases. For example, there is an excellent table comparing and contrasting the forms of vascular malformation and another that explains the complicated imaging features of hemorrhage as it evolves on the different imaging sequences.
In the Internet era, even medical textbooks have their own Web sites, and this case is no exception. Although in part an advertisement for the book, the site currently offers 29 additional teaching file cases for free viewing and is growing-perhaps these cases are to be included in a future book or CD-ROM edition. These online cases supplement the text, but also include eight cases in a new category-skull. For thrifty Web surfers hoping to download the whole book, be warned that the 167 cases in the book are not on the Web site; those considering purchase of the book are encouraged to visit the site, however, because the online cases there are of the same format as those found in the book.

Minor criticisms include the inclusion of a small number of marginal quality images, particularly a few noisy CT scans with narrower gray scale windowing than is usually seen on film. The MRI reproductions are of uniformly excellent quality and all the figures well illustrate the intended findings. Some neurologists might be offended by the brief one-sentence clinical presentations and may wish to know more clinical history and perhaps a few words on how the diagnosis was established and what the outcome was. Like most teaching atlases directed toward radiologists, however, this book focuses on the imaging, and it is the beautiful illustrations that make this book stand out from the rest.

Overall, this book will be a valuable addition to a Neurology departmental library or clinic or as an aid for residents preparing for their board examinations. It condenses into a highly readable format the best cases from perhaps two decades of neuroradiology case conferences at one of the premiere departments.

Dean Shibata, $M D$

Copyright $\odot 2001$ by AAN Enterprises, Inc.

\title{
Correction
}

\section{Practice parameter: Evidence-based guidelines for migraine headache (an evidence-based review): Report of the} Quality Standards Subcommittee of the American Academy of Neurology

In the article "Practice parameter: Evidence-based guidelines for migraine headache (an evidence-based review): Report of the Quality Standards Subcommittee of the American Academy of Neurology" (Neurology 2000;55:754-763) by Silberstein et al., there was a misprint in table 2 . The third line of the table legend should have been preceded by a $\ddagger$ symbol, not a $\uparrow$ symbol.

Table 4 contained three errors. Under the column heading "Group 2," the drug name "naproxen" was spelled incorrectly. Also, "fluoxetine (racemic)" and "gabapentin" should have been listed under Group 2, not Group 1. There have also been some deletions and additions. The corrected table 4 is printed below in its entirety.

Table 4 Preventive therapies for migraine*

\begin{tabular}{|c|c|c|c|c|}
\hline Group $1 \dagger$ & Group $2 \ddagger$ & Group $3 \S$ & Group 4II & Group 5\| \\
\hline $\begin{array}{l}\text { Amitriptyline } \\
\text { Divalproex sodium } \\
\text { Propranolol/timolol }\end{array}$ & $\begin{array}{l}\text { B-blockers } \\
\text { Atenolol/metoprolol/nadolol } \\
\text { Ca-blockers } \\
\text { Nimodipine/verapamil } \\
\text { NSAIDs } \\
\text { Aspirin/fenoprofen/flurbiprofen } \\
\text { Ketoprofen } \\
\text { Mefenamic acid } \\
\text { Naproxen } \\
\text { Naproxen sodium } \\
\text { Fluoxetine (racemic) } \\
\text { Gabapentin } \\
\text { Other } \\
\text { Feverfew } \\
\text { Magnesium } \\
\text { Vitamin B2 }\end{array}$ & $\begin{array}{l}\text { A: Antidepressants } \\
\text { Bupropion } \\
\text { Doxepine } \\
\text { Fluvoxamine } \\
\text { Imipramine } \\
\text { Mirtazepine } \\
\text { Nortriptyline } \\
\text { Paroxetine } \\
\text { Protriptyline } \\
\text { Sertraline } \\
\text { Trazodone } \\
\text { Venlafaxine } \\
\text { Other } \\
\text { Cyproheptadine } \\
\text { Diltiazem } \\
\text { Ibuprofen } \\
\text { Topiramate } \\
\text { B: (side effect concerns) } \\
\text { Phenelzine }\end{array}$ & Methysergide & $\begin{array}{l}\text { Carbamazepine } \\
\text { Clomipramine } \\
\text { Clonazepam } \\
\text { Clonidine } \\
\text { Indomethacin } \\
\text { Nicardipine } \\
\text { Nifedipine } \\
\text { Pindolol }\end{array}$ \\
\hline $\begin{array}{l}\text { * Does not include cc } \\
\dagger \text { Medium to high ef } \\
+ \text { Lower efficacy thar } \\
\S \text { Clinically efficacio } \\
\text { II Medium to high ef } \\
\| \text { Evidence indicating }\end{array}$ & $\begin{array}{l}\text { ation products. } \\
\text { good strength of evidence, and mi } \\
\text { elisted in first column, or limited } \\
\text { ed on consensus and clinical exper } \\
\text { good strength of evidence, but wi } \\
\text { ficacy over placebo. }\end{array}$ & $\begin{array}{l}\text {-moderate side effects. } \\
\text { ngth of evidence, and mild-to } \\
\text { de but no scientific evidence concerns. }\end{array}$ & & \\
\hline
\end{tabular}




\title{
Neurology
}

\author{
Book Review \\ Dean Shibata \\ Neurology 2001;56;142 \\ DOI 10.1212/WNL.56.1.142
}

This information is current as of January 9, 2001

\section{Updated Information \&}

Services

Permissions \& Licensing

Reprints including high resolution figures, can be found at: http://n.neurology.org/content/56/1/142.1.full

Information about reproducing this article in parts (figures,tables) or in its entirety can be found online at:

http://www.neurology.org/about/about_the_journal\#permissions

Information about ordering reprints can be found online:

http://n.neurology.org/subscribers/advertise

Neurology ${ }^{\circledR}$ is the official journal of the American Academy of Neurology. Published continuously since 1951, it is now a weekly with 48 issues per year. Copyright. All rights reserved. Print ISSN: 0028-3878. Online ISSN: 1526-632X.

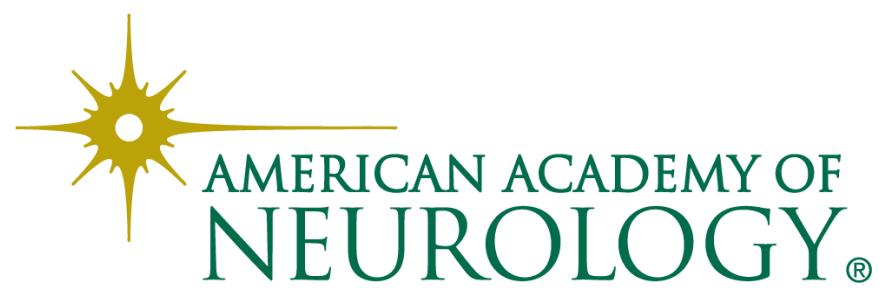

